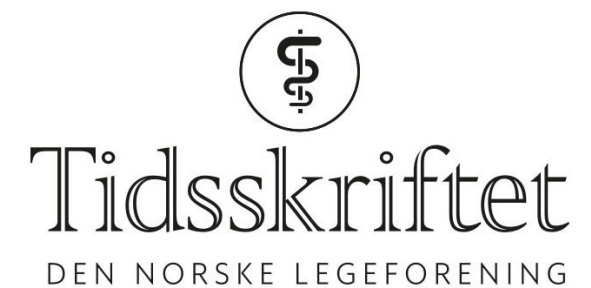

DEN NORSKE LEGEFORENING

\title{
Legemets oppstandelse og det evige liv
}

FRA REDAKTØREN

\section{ARE BREAN}

Are Brean (f. 1965) er sjefredaktør i Tidsskriftet. Han er spesialist i nevrologi og ph.d.

På den andre siden av døden venter en ny kropp eller et virtuelt selv, for den som tror - eller er villig til å betale.

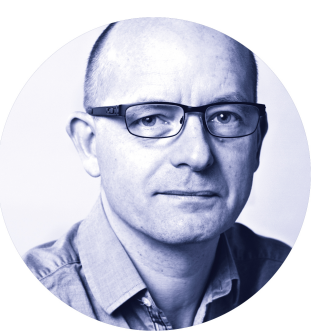

Foto: Einar Nilsen

Drømmen om evig liv - om å seire over døden ved å frigjøre jeget fra den besværlige kroppen - har fulgt menneskene til alle tider og er sentral i alle de store religionene. Men mens streben for et lengst mulig liv alltid har vært en del av legenes og medisinens domene, har drømmen om det evige liv stort sett tilhørt religionen. Unntaket er i de mer fantasifulle ytterkantene av vitenskapen, i de senere år revitalisert som en del av den såkalte transhumanismens tankegods (1).

Og nå er vi i gang igjen: I november 2017 kom nyheten om at kirurgene Sergio Canavero og Ren Xiaoping har lyktes i å transplantere kroppen fra et lik over på et annet liks hode (2). Ifølge Canavero var operasjonen en suksess. Neste fase - den samme operasjonen utført på to hjernedøde mennesker - skal være nær forestående. Deretter skal skrittet tas fullt ut, og verdens første transplantasjon av et levende hode over på en ny kropp skal utføres i 2018, fortsatt ifølge Canavero (3).

En slik spektakulær operasjon har vært en hellig gral helt siden den franske nobelprisvinneren Alexis Carrel i 1908 transplanterte hodet fra én hund over på en annen (4). Hodet hadde en kort stund enkelte visuelle og kutane reflekser før dyret ble avlivet. I 1950- og 6o-årene ble det utført lignende transplantasjoner på ulike dyrearter, der dyret hadde en levetid på noen timer til dager (4). Fart i forhåpningene ble det imidlertid ikke før utviklingen av immunsuppressiver gjorde omfattende allotransplantasjoner mulig, så som den første vellykkede fulle ansiktstransplantasjon i 2006 (4). Men derfra og til å hindre avstøtning ved full kroppstransplantasjon er fortsatt et langt og usikkert steg. Det største tekniske hinderet er likevel sammenkoblingen av nervevevet mellom donor og mottager. 
Nye kirurgiske teknikker og utviklingen av "fusogener», polymerer som fusjonerer cellemembraner, har gitt håp til mennesker med ryggmargsskade. Likevel, å sette sammen en avrevet medulla er ennå langt fra gjennomførbart hos ryggmargsskadede - for ikke å snakke om mellom to ulike individer, som ved en kroppstransplantasjon.

I tillegg til de teknisk uløste utfordringene ved kroppstransplantasjon er det en rekke medisinske, juridiske og etiske aspekter som er mildest talt problematiske. For å nevne noen: Troen på at et menneskes opplevelse av et «jeg» er en rent kognitiv prosess - altså noe som er avgrenset til hjernen alene - er i dag stort sett forlatt i nevrovitenskapen. Hjernen er ikke alene; gjennom hele individets ontogenese formes den av, og former, kroppen den tilhører. Sensorisk og motorisk informasjon fra kroppen er en nødvendig del av selvopplevelsen (5). Milliarder av signaler mellom hjernen og en helt ny kropp vil kunne gi stor fare for sammenbrudd i selvopplevelsen, med resulterende psykose og i verste fall $\mathrm{d} ø \mathrm{~d}$ (6). Juridisk er dertil bare noe så grunnleggende som pasientsamtykke problematisk i en slik giver-donor-situasjon. Etisk er det også tvilsomt om det lar seg forsvare å la en hel donorkropp tilfalle én pasient og ikke de mange andre organtrengende den ellers kunne ha hjulpet. Og hva med de to givernes personlige juridiske rettigheter - tilhører de hodet eller kroppen til «den nye» personen?

Lovnaden fra Sergio Canavero om en snarlig kroppstransplantasjon er altså forhåpentligvis overdreven. Men han og andre kroppstransplantasjonsoptimister er ikke de eneste med håp om at evig liv kan oppnås med medisinsk teknologi. Kryonikk - nedfrysing av hjernen eller hele kroppen etter døden - med håp om gjenoppliving i en fremtid der kroppen kan gis nytt liv eller hjernen gis ny kropp, øker i popularitet. Dette til tross for nærmest fullstendig fravær av vitenskapelige holdepunkter for fremtidig opptiningssuksess (7). Tvert imot: Ved nedfrysing bevares i heldigste fall anatomien - altså informasjonen om hjernens konnektivitet. Men det er minst like mye i hjernens funksjonalitet - de levende forskjellene i genregulering, kjemisk mikromiljø og lokal og regional dynamikk av signalsubstanser - at individets nevrobiologiske bumerke sitter. Mye på samme måte som en levende by ikke bare er dens veier og bygninger, men like mye den aktiviteten som foregår der. Har man kun informasjon om konnektiviteten, er man ikke i nærheten av å fange det tenkende, følende individ. Troen på at hjernen skal kunne våkne opp som seg «selv» etter nedfrysing, er altså i beste fall naiv, i likhet med troen på at informasjonen i den opptinte hjernen skal kunne lastes opp til fremtidige superdatamaskiner som skal gi selvet evig virtuelt liv (8). Like fullt tilbyr smarte forretningsfolk nedfrysing for rundt 100 ooo amerikanske dollar per hjerne, godt hjulpet av «vitenskapelig» utseende nettsider og smart markedsføring overfor en voksende kundegruppe (9). Som så ofte ellers synes betalingsvilligheten å være direkte proporsjonal med naiviteten.

Kroppstransplantasjon, kryonikk og opplasting av det virtuelle selvet har det til felles at de lover oss noe mer på den andre siden av det vi frykter mest: den uavvendelige døden. Dette er tradisjonelt religionens domene. Det er gode vitenskapelige grunner til å fortsette å la det være slik. Det er det verdt å minne om når vi snart går inn i den kristne religions største høytid, med dens fortelling om den udødelige guddommen som fødtes som et dødelig menneske.

\section{LITTERATUR:}

1. Humanity+. http://humanityplus.org/(4.12.2017).

2. Osborne H. Head Transplants: Sergio Canavero Is About to Perform the First Human Surgery-and

There's Nothing to Stop Him. Newsweek 13.11.2017.

http://www.newsweek.com/head-transplant-surgeon-sergio-canavero-dangerous-maverick-medical-re volution-709332 (4.12.2017).

3. Johnsen P. Hodeløst fremskritt. Morgenbladet 24.11.2017.

4. Lamba N, Holsgrove D, Broekman ML. The history of head transplantation: a review. Acta Neurochir 
(Wien) 2016; 158: 2239-47. [PubMed][CrossRef]

5. Meteyard L, Cuadrado SR, Bahrami B et al. Coming of age: a review of embodiment and the neuroscience of semantics. Cortex 2012; 48: 788 - 804. [PubMed][CrossRef]

6. Čartolovni A, Spagnolo AG. Ethical considerations regarding head transplantation. Surg Neurol Int 2015; 6: 103. [PubMed][CrossRef]

7. Hendricks M. The false science of cryonics. MIT Technology Review 15.9.2015.

https://www.technologyreview.com/s/541311/the-false-science-of-cryonics/ (4.12.2017).

8. Miller KD. Will you ever be able to upload your brain? The New York Times 10.10.2015.

https://www.nytimes.com/2015/10/11/opinion/sunday/will-you-ever-be-able-to-upload-your-brain.html ?_r=2 (4.12.2017).

9. Cryonics Institute. 2017. Cryonics Institute. http://www.cryonics.org/ (4.12.2017).

Publisert: 12. desember 2017. Tidsskr Nor Legeforen. DOI: 10.4045/tidsskr.17.1062

(C) Tidsskrift for Den norske legeforening 2020. Lastet ned fra tidsskriftet.no 